\title{
Factors to Develop Man for Others and Man of God: National Identity as a Nation Who Believes in The One and Only God
}

\author{
A. Gunardi ${ }^{1,2}$, C Siregar ${ }^{3}$ \\ ${ }^{1}$ Character Building Development Center, Information Systems Department, School of \\ Information System, Bina Nusantara University, Jakarta, Indonesia \\ ${ }^{2} \mathrm{PhD}$ Student in Psychology, Atma Jaya Catholic University Indonesia, Jakarta, Indonesia \\ ${ }^{3}$ Character Building Development Center, Communication Department, Faculty of Economics \\ \& Communication, Bina Nusantara University, Jakarta, Indonesia \\ 1andyprjk@binus.ac.id
}

\begin{abstract}
Indonesia is a country having foundation as Pancasila regarded as a base and vision of the country, therefore all activities and programs to build the structures and infra structures are based on Pancasila. The first principle of Pancasila is belief in the One and Only God. This principle needs to develop and to be accepted in all Indonesians in order to enforce and to embed the principle, Researcher tries to interview some Dedicated Catholic Priests how to live on their own religiosity and help their societies. Catholic Priests are strictly chosen because of their long education to be priest (is about 10 years after high school); their commitment to help communities, and their dedication to serve God. Through this, Researcher hopes it can strengthen the first principle of Pancasila to be embedded in Indonesian heart.
\end{abstract}

Keywords: Pancasila, Indonesia, God

\section{INTRODUCTION}

Indonesia is a country having various languages, ethnics, cultures, and religions. To bring togetherness as a country, the founder parents (expressing there are men and women) defined Pancasila as foundation. In the first principle, religions are united as belief in the One and Only God. The Founders hope that religions accepted become an identity of Indonesian. Each religion is equal in rights and in the law. To bring the awareness and embrace the meaning of this principle, Researcher is interested in finding factors that can develop humanity and religiosity.

The terms of man for others and man of God are in one coin with different side. It means that the terms can be seen as two but one. When people try to serve and help the others, they serve God and reversely, when people serve God, they serve the others [1].

\subsection{Man for Others}

The term of Man for others can be seen much in the Christian context. The meaning of this term is a man who want to do good to the others. This term is similar with the term of altruism. 
Batson defines altruism as an act of helping others, though it will certainly involve some cost [2]. According to Dettoni [3] the concept can be founded by Heidegger's theory.

They describe the term in Man: Being-In-The World-with-Others. There are three steps: the first is the world; the second is the history and the third is the man itself. The world is an environment that can be designed by man through languages. Man lives in the world and meet with another men, creatures and environment. They find meaning in the context of existential. The process makes history and the history brings hope to their future [3]. Through this theory men cannot being alone, but always with the others. The concept of others in the context Heidegger's theory is not only the other men but including the other creatures and environments.

In the context of human relationship, the connection can be influenced the level of human well-being. Langman and Chung mention that the spiritual and forgiveness factors associated with human well-being [4]. It means that good relation and help each other will bring the quality of human life. It can say treating well the others will bring the humanity of mankind.

\subsection{Man of God}

The term of man of God comes from Christian context. It means that people follow God in every way of life in order to serve God freely and joyfully (Micah 6:8). In this context Researcher wants to elaborate more from the other tradition such as psychology, other religions and also in Christian context.

Frankl tried to find out how people bearing heavy burden and bad situations can survive the life [5]. He questioned why people in the Nazi's camp concentration did not commit suicide when they experienced lost families and tortured. He found that searching of meaning made them struggle during hard situations. In this case experiencing God through their life makes people survive and live through.

Sorajjakool did research in Thailand for under age children who working in prostitution. He mentioned that the way that God can be experienced by those children is pastoral counselling [6]. For that reason, he encourages counselors to work on those children to bring God in their live.

Tobroni did research in five Islamic schools in Indonesia [7]. He found that school bringing up the spiritual leadership is better to develop in management and also better life. The students learn how to be better human and also obey God through their live.

Tan \& Castillo said that having self-care is needed but not enough [8]. In the perspective of psychology and Christianity they found that people need to be aware of God's care and community's care. Through the life that served God and lived in the Christian's community people experience healing, helping, strengthening and encouraging each other.

\section{METHOD}

The question that will arise to develop man for others and man of God is how to find which factors that will give contribution to construct the man for others and man of God. This research is derived from phenomenological research from [9]. Researcher will do depth interview to three catholic priests who have dedicated among Catholic Priests in The Archdiocese of Jakarta. Researcher uses his experiences as Catholic Priest in Jakarta and as a vice communion of 
Archdiocese catholic priests and has permission from Archbishop to select which priests to choose.

The Researcher uses stratified sampling such as interview one senior priest (75 years old); one middle age of Priest (59 years old) and one junior priest (38 years old). Through this sampling, Researcher hopes they can represent three generations of priests in Jakarta. (note: To be catholic priest at least is about 29 years old)

The researcher did interview priests until there are no more new data having collected data, Researcher use epoche, phenomenological reduction, synthesis meaning and essences. The credibility of this research is gained through confirmation from respondents.

\section{RESULTS AND DISCUSSION}

The researcher interviews three Catholic Priests: Fr. Ali, Fr. Beni and Fr. Cornel (they are not real name). According to the results, the Researcher finds 3 dimensions; Base motivation, Qualities of Life; and Competencies. The three cannot separated each other, but as one entity.

\subsection{Base Motivation}

The first that priest experience following God in their life is base motivation. It is the source how and why they want to be religious. They find meaning in the way that they want to serve. "The most important thing is base motivation. On my reflection I choose this way because this is my own choice. I need to be frank and commit, especially to follow the schedule of prayer in the morning and evening. Though, I am tired but I need to make it" (Fr Ali).

According to Fr Ali, the challenges in life depend on how strong the base motivation is. If priests stick to the motivation he will pass them. The motivation will encourage and empower priests to face all obstacles. Fr Benny and Cornel have the same experiences in expression of impression of priests that they experienced in their childhood.

"What is the decision to be a priest for? It comes because of the admiring priest" (Fr. Ali)

The amazing sacrifice of Christ can be seen in the life of missionaries. They live in modern country but they want to leave and stay in the village of rural regions. They want to sacrifice their life" (Fr. Beni).

"Actually, the factor that I want to be a priest is religious environment in the village. There are Brother, Sister, Priests who introduce religious style and life to people. From that moment I want to be a priest. I love to be altar boy in the church and serving people in the village" (Fr. Cornel).

The admires of priest's life is a sign of God's call. The priests become role model in their childhood life. According to [10] the phenomena that bring to imitation and identification can be called as modelling. In this context there is something new in their life, something that they never experience before that's the goodness (rewards). It will be referred in Fr Ali's expression on the personal admire; Fr. Beni's expression on priest sacrifice; Fr Cornel's admire on religious environment by priests. The positive perception will bring identification [10] . 
Burke and Stets define identification as collection of meanings that define a person when he or she is in the special particular place of role in the organization or society or group and express the character as a unique person [11]. When Fr. Ali, Beni and Cornel enter the seminary (school for candidate of priests) they are in such identification. They play role as priests when they follow ten years of education after high school. The factor that makes them survive is a base motivation that is the call to answer God that is signed by interested in to be priest.

\subsection{Qualities of Life}

The quality of life can be defined as an individual measurement about goodness that the person has in all aspect of life such as human relationship, self-regulation and self-efficacy [12]. The quality of life is related to subjective well-being that can be expressed by gratitude [13]. To be a good priest the qualities of life that need to having spiritual life, study life, and community life. They will bring meaning and all experiences to gratitude [14][15]. They bring also the spirit to face all obstacles in life.

\subsubsection{Spiritual Life.}

According to the interview, researcher finds that spiritual life is the most important thing such as building relationship with God, closing to the Word, willingness to sacrifice, and gratitude toward life, and mystic experience with God. The good relationship with God can be expressed through good relationship with Bishop, their leader. The key to be that person is humility.

"First is about spiritual life, priest must be a witnes of good relationship with God. It can be called as Teacher of Prayer. Prayer is not just official prayer but making the life of prayer. So, the first is spiritual life" (Fr. Ali).

"At the end of this journey the question may be raised is that "what is the purpose of life?" To be a priest is a way to God and also to live in the family. Being unmarried is a way of priesthood" (Fr. Ali).

"My dream is to follow Jesus who call me to be a priest. My model in life is Jesus as a Shepherd" (Fr. Cornel).

The mystic experience is to meet God personally and bring gratitude and courage in all aspect of life. According to Pearson this relationship is to meet the archetype [16]. The archetype brings the God's presence in one's life. The person is aware of the essence of his life [16][17].

\subsubsection{Study Life.}

To be a priest, one needs to spend at least ten years after high school of education. He must study philosophy and theology and experience of work in the field of religion at least two years. The long of this study is meant to make a habit of study. A priest must study all the time to answer the challenges of people experiences and bring update to their work.

In my experience there is a priest asking me to be his spiritual director and I encourage him to study well and now he has become a secretary in the one diocese (Fr. Beni)

In the spirit of study, a priest transforms his life through experiences that will bring something that they not know before to the new knowledge. This learning is not only to have a 
specific skill, but also to be more aware of life's meaning in reflection process. This kind of learning is a process of individuation in Carl Jung theory [18].

\subsubsection{Community Life.}

Priests live in a community. They are assigned with partner and never be alone. Through living in the community, each priest can share his experience, help each other [19] and encourage each other and also pray together.

In the context of psychology, living in the community will bring a well-being like in the community of support, priest will get a healthy[20]. In the term of community psychology, community is a part of one's personal life contained with relationship values that built working together to make them exist [21]. This can be seen in the relationship of priests in the community. If a priest has a good communication with the other priest in the community, it means that they can keep the value as priest.

"The indicator is that simply, to live in the community as internal factor and external that is relationship with lay people. Just imagine when a priest is assigned to work in one place where he cannot choose whom his partner is. He can be moved from one place to the other place and if he cannot build the good relationship each other how come he wants to serve God in that place" (Fr. Ali).

"Our identity can be seen through community building. That is a sign and also a witness to the others" (Fr. Cornel).

When priests make a good relationship with the other priest and also parishioners, they can help each other and keep their call to be priest.

\subsection{Competencies}

Competencies are distinctive elements necessary for competence that correlate with performance and can be evaluated against agreed upon standards[22]. According to [23] selfefficacy is related with someone's job, moreover, when the job is synchronized by his call.

According to the depth interview, priests must have three competencies: governing, teaching and sanctifying. The governing in this context is similar with servant leadership that is defined by [24]. He defined the servant leadership as the new kind of leadership which having main purpose to serve the others.

"The risk is to accept people burden as our burden in order to be ready to serve all the time" (Fr Beni)

"So, the ability is to know well what parishioners need and how to help them" (Fr. Ali)

"I am so grateful when I can help people who want to build a new family and guide them to their family life especially when they have problems" (Fr. Cornel).

Teaching is to bring good news to all people. Priests need to be expert in preaching. This is not about the interesting material but how to bring the Word to be a life. "The priest is not only talking about theology, but also to helping parishioners find a way out the difficulties of life". (Fr. Ali)

Sanctifying is to make people holy. It means transforming parishioners' life from bad to good, from unfaithful to faithful, from unknowledge to knowledge, etc. Priest can differentiate which one is good and not. The priest can bring unifying and prevent hostility (Fr. Cornel). He has good morality to give advice and witness. 


\section{CONCLUSION}

Through this research, researcher finds that the factors that can build man for others and man of God are base motivation, qualities of life and competencies as well. The base motivation is a willing that come from God that can bring a person to know what they want to do in their life. The qualities of life are aspects needed to fulfill gaining good life and faith. The competencies are the skill and ability to do jobs properly from time to time. Through the three factors people can be meaningful to the others and be faithful to God.

The three factors can develop the first principle of Pancasila. The awareness of our founder parents about unity as a nation in the believe of One can be sustained through developing the three. In the past the unity of religions was needed to fight obvious enemy such as colonial, but today when imperialism is not present they need a reason to live together in differences and to make the unity continues. That is not from outside but from inside and the tree factors will help.

Researcher is aware of the limitation of this work so that he needs to continue with other work such as quantitative research. Base on the depth interview, Researcher can make measurement which factor will be more effective than others. After that he can evaluate and make module to galvanize young adults to love neighbor and God.

\section{REFERENCES}

[1] M. J. Clark, "Love of God and Neighbor: Living Charity in Aquinas' Ethics," New Blackfriars, vol. 92, no. 1040, pp. 415-430, Jul. 2011.

[2] C. D. Batson, Altruism in Humans. Oxford: Oxford University Press, 2010.

[3] L. L. Dettoni, J. L. Dettoni, and J. L. Dettoni, "O Homem : Ser-No-Mundo-Com-OsOutros," Clareira-Revista Filos. Da Reg. Amaz., vol. 3, no. 2, pp. 103-113, 2016.

[4] L. Langman and M. C. Chung, "The Relationship Between Forgiveness, Spirituality, Traumatic Guilt and Posttraumatic Stress Disorder (PTSD) Among People with Addiction," Psychiatr. Q., vol. 84, no. 1, pp. 11-26, Mar. 2013.

[5] V. E. Frankl, Man's Search for Meaning. Boston: Beacon Press, 1959.

[6] S. Sorajjakool, "Theological and Psychological Reflection on the Functions of Pastoral Care in the Context of Child Prostitution in Thailand," J. Pastoral Care, vol. 54, no. 4, pp. 429-439, Dec. 2000.

[7] Tobroni, "Spiritual Leadership: a Solution of the Leadership Crisis in Islamic Education in Indonesia," Br. J. Educ., vol. 3, no. 11, pp. 40-53, 2015.

[8] S.-Y. Tan and M. Castillo, "Self-Care and Beyond: A Brief Literature Review from a Christian Perspective," J. Psychol. Christ., vol. 33, no. 1, pp. 90-95, 2014.

[9] C. Moustakas, Phenomenological research methods. \{SAGE\} Publications, Inc., 1994.

[10] A. Bandura, Psychological Modeling: Conflicting Theories. Milton Park: Routledge, 2006.

[11] P. J. Burke and J. E. Stets, Identity Theory. Oxford: Oxford University Press, 2009.

[12] E. Diener, E. M. Suh, R. E. Lucas, and H. L. Smith, "Subjective well-being: Three decades of progress.," Psychol. Bull., vol. 125, no. 2, pp. 276-302, 1999.

[13] N. I. Chuprikova, "The Completion of Temporary Connections Through Speech," Sov. Psychol., vol. 10, no. 3, pp. 276-302, Apr. 1972.

[14] S. A. Christanto, D. Brenda, C. Assisiansi, M. J. Pangestu, I. Sarita, and V. Sulistiani, "Gratitude Letter: An Effort to Increase Subjective Well-Being in College," ANIMA Indones. Psychol. J., vol. 32, no. 3, p. 158, Apr. 2017. 
[15] A. Efklides and D. Moraitou, "Introduction: Looking at Quality of Life and Well-Being from a Positive Psychology Perspective," New York: Springer, 2012, pp. 1-14.

[16] C. S. Pearson, Awakening The Heroes Within. London: Bravo Ltd, 2016.

[17] R. A. Johnson, Inner Work: Using Dreams \& Active Imagination for Personal Growth. New York: Harper One, 1986.

[18] C. G. Jung and E. Humbert, The Fundamentals of Theory and Practice. Wilmette: Chiron Publication, 1988.

[19] H. Leteng, Spritualitas Imam Praja. Yogyakarta: Kanisius, 2010.

[20] Urie Bronfenbrenner, The Ecology of Human Development-Experiments by Nature and Design. Cambridge: Harvard University Press, 1979.

[21] G. N. Prilleltensky, Community Psychology in Pursuit of Liberation and Well Being. New York: Palgrave Macmillan, 2010.

[22] N. J. Kaslow, S. E. Dunn, and C. O. Smith, "Competencies for Psychologists in Academic Health Centers (AHCs)," J. Clin. Psychol. Med. Settings, vol. 15, no. 1, pp. 18-27, Mar. 2008.

[23] A. S. Indramawan, "Self-Efficacy, Meaning of Work as Vocation, and Work Engagement of High School Teachers in Surabaya," ANIMA Indones. Psychol. J., vol. 31 , no. 1 , p. 30 , Oct. 2015.

[24] G. R K, On Becoming a Servant Leader. San Fransico: Josey-Bass, 1996. 